\title{
Biohydrogen Production and Kinetic Modeling Using Sediment Microorganisms of Pichavaram Mangroves, India
}

\author{
P. Mullai, ${ }^{1}$ Eldon R. Rene, ${ }^{2}$ and K. Sridevi ${ }^{1}$ \\ ${ }^{1}$ Pollution Control Research Laboratory, Department of Chemical Engineering, Annamalai University, Annamalai Nagar, \\ Tamil Nadu 608 002, India \\ ${ }^{2}$ Core Group Pollution Prevention and Resource Recovery, Department of Environmental Engineering and Water Technology, \\ UNESCO-IHE, P.O. Box 3015, 2601 DA, Delft, The Netherlands \\ Correspondence should be addressed to P. Mullai; pmullai@yahoo.in
}

Received 11 September 2013; Accepted 11 October 2013

Academic Editor: Kannan Pakshirajan

Copyright (C) 2013 P. Mullai et al. This is an open access article distributed under the Creative Commons Attribution License, which permits unrestricted use, distribution, and reproduction in any medium, provided the original work is properly cited.

Mangrove sediments host rich assemblages of microorganisms, predominantly mixed bacterial cultures, which can be efficiently used for biohydrogen production through anaerobic dark fermentation. The influence of process parameters such as effect of initial glucose concentration, initial medium $\mathrm{pH}$, and trace metal $\left(\mathrm{Fe}^{2+}\right)$ concentration was investigated in this study. A maximum hydrogen yield of $2.34,2.3$, and $2.6 \mathrm{~mol} \mathrm{H}_{2} \mathrm{~mol}^{-1}$ glucose, respectively, was obtained under the following set of optimal conditions: initial substrate concentration $-10,000 \mathrm{mg} \mathrm{L}^{-1}$, initial $\mathrm{pH}-6.0$, and ferrous sulphate concentration $-100 \mathrm{mg} \mathrm{L}^{-1}$, respectively. The addition of trace metal to the medium $\left(100 \mathrm{mg} \mathrm{L}^{-1} \mathrm{FeSO}_{4} \cdot 7 \mathrm{H}_{2} \mathrm{O}\right)$ enhanced the biohydrogen yield from $2.3 \mathrm{~mol} \mathrm{H}_{2} \mathrm{~mol}^{-1}$ glucose to $2.6 \mathrm{~mol} \mathrm{H}_{2} \mathrm{~mol}^{-1}$ glucose. Furthermore, the experimental data was subjected to kinetic analysis and the kinetic constants were estimated with the help of well-known kinetic models available in the literature, namely, Monod model, logistic model and Luedeking-Piret model. The model fitting was found to be in good agreement with the experimental observations, for all the models, with regression coefficient values $>0.92$.

\section{Introduction}

Fossil Fuels are the primary energy source for the world's increasing energy consumption. According to a recent survey, total world energy use rises from 524 quadrillion British thermal units (Btu) in 2010 to 630 quadrillion Btu in 2020 and to 820 quadrillion Btu in 2040 [1]. This fossil fuel eventually leads to foreseeable depletion due to limited energy resources; however, in the last few years, research and development activities pertaining to large-scale production of alternate resources of energy such as biodiesel, biohydrogen and bioethanol have risen [2-8]. In the days of fast depleting fossil fuel, biohydrogen has become a promising and viable energy source owing to its inherent advantages: zero-pollution, carbon-free, inexhaustible, recyclable, and highest energy density. However, most of hydrogen is currently produced from non-renewable sources using natural gas $(50 \%)$, petroleum-derived naphthenes and distillates
$(30 \%)$, coal $(18 \%)$, and electricity produced from variety of fuels $(2 \%)$. Since this strategy leads to the depletion of non-renewable energy sources and is considered as a less ecofriendly alternative, it becomes crucial to go in for the production of sustainable energy source.

Biohydrogen production through anaerobic fermentation is a sustainable alternate for the energy crisis and green environment [9-12]. Fermentative hydrogen production processes are technically feasible and economically competitive and have large-scale commercialization possibilities $[8,13-$ 16]. The present work focuses on biohydrogen production by dark fermentative approach using mangrove sediments of Pichavaram (located in Tamil Nadu, India). It is known that no research has been made using the sediments of mangroves, new mixed consortia to produce biohydrogen. Mangrove sediments are inherently rich in organic content [17-19]. The advantages of this sediment can be summarized as follows: flexible substrate utilization and the simplicity 
of handling, no major storage problems, no problems with strain degradation, no preculturing required, and sediments are available at low cost.

A kinetic model can adequately describe the relationship among the different state variables and explain the behavior of fermentation quantitatively by providing useful information that can be subsequently used for analysis, design, and operation of any fermentation process [20-22]. The unstructured kinetic models are frequently employed for modeling microbial systems because they are simple, yet can provide useful information about the process $[11,23,24]$. In this study, three unstructured kinetic models, namely, Monod, logistic, and Luedeking-Piret models $[25,26]$ were used to determine the kinetic parameters.

\section{Materials and Methods}

2.1. Selective Enrichment on Biohydrogen Producing Mangrove Sediments. The sediments were collected from the mangrove rhizosphere of Pichavaram, Tamil Nadu, India, at a depth of $100 \mathrm{~cm}$, and later stored in sterile polythene bags. Heatshock treatment was done on this sediment sample, by constant heating at $110^{\circ} \mathrm{C}$ for $2 \mathrm{~h}$, in order to stimulate spore germination and eliminate all vegetative cells, particularly methanogens. The coarse particles were removed using a stainless steel mesh, while the finer fractions were stored at $4^{\circ} \mathrm{C}[27]$.

2.2. Nutrient Medium. The nutrient medium (non-sterilized) used in this study had the following chemical composition (per litre): $\mathrm{NH}_{4} \mathrm{Cl}-0.5 \mathrm{mg}, \mathrm{K}_{2} \mathrm{HPO}_{4}-0.25 \mathrm{mg}$, $\mathrm{MgCl}_{2} \cdot 6 \mathrm{H}_{2} \mathrm{O}-0.3 \mathrm{mg}, \mathrm{NiSO}_{4}-0.016 \mathrm{mg}, \mathrm{CoCl}_{2}-0.025 \mathrm{mg}$, $\mathrm{ZnCl}_{2}-0.0115 \mathrm{mg}, \mathrm{CuCl}_{2}-0.0105 \mathrm{mg}, \mathrm{CaCl}_{2}-0.005 \mathrm{mg}$, and $\mathrm{MnCl}_{2}-0.015 \mathrm{mg}$.

2.3. Batch Experiments. Batch tests were conducted in duplicate, in $1 \mathrm{~L}$ Erlenmeyer flasks (working volume: $0.7 \mathrm{~L}$ ), fitted air-tightly with rubber septum, and adequately sealed using commercially available fix gels. The effect of process parameters on biohydrogen yield, namely, the influence of initial substrate concentration (glucose), initial $\mathrm{pH}$, and trace metal, $\mathrm{Fe}^{2+}$ concentration, was evaluated by carrying out experiments at different low to high levels of these parameters, and the average values of biohydrogen yield were presented. The $\mathrm{pH}$ of the growth medium was adjusted using $1 \mathrm{~N} \mathrm{HCl}$ or $1 \mathrm{~N} \mathrm{NaOH}$ during the start of the experiments. The growth medium was inoculated with $100 \mathrm{~g}$ of pretreated sediment under aseptic conditions, and the flasks were incubated at $35^{\circ} \mathrm{C}$ for fermentation.

2.4. Analytical Methods. The biohydrogen gas was measured using wet gas flow meter (Toshniwal, India). The gas content was analyzed using a gas chromatograph (Shimadzu, 221-70026-34, Japan) equipped with a thermal conductivity detector (TCD), and the column was packed with dual packed column. The operating temperatures of the column, detector and injector, were $40^{\circ} \mathrm{C}, 80^{\circ} \mathrm{C}$, and $50^{\circ} \mathrm{C}$, respectively. Biomass concentration was measured as volatile suspended solid (VSS) and analyzed according to Standard Methods [28]. Glucose concentration was measured by DNS method using spectrophotometer (Elico, India) at a $\lambda_{\max }$ of $550 \mathrm{~nm}$ [29]. The sludge granules were characterized using scanning electron microscope (SEM) (JEOL-JSM, 5300, Japan) at a resolution of $4.5 \mathrm{~nm}$ at $15 \mathrm{kVA}$ with a working distance of $8 \mathrm{~mm}$.

\section{Results and Discussion}

Biohydrogen fermentation reached nearly constant values at the end of $120 \mathrm{~h}$ for each batch tests, including their duplicates. Glucose degradation efficiencies, cumulative biohydrogen gas, and hydrogen yields were calculated for each set of experimental condition.

3.1. Effect of Initial Glucose Concentration. For initial glucose concentrations of 4,000,7,000,10,000, 13,000, and $16,000 \mathrm{mg} \mathrm{L}^{-1}$, the values of cumulative biohydrogen production and glucose degrading efficiencies were 430, 1190, 2600, 2200 , and $2099 \mathrm{~mL}$ and $75,83,90,80$, and $72 \%$, respectively (Figure 1). The effect of initial glucose concentration was observed when the initial medium $\mathrm{pH}$ was kept constant at 6.0 for all the test vials. It was observed that biohydrogen production increased with an increase in glucose concentration from 4,000 to $10,000 \mathrm{mg} \mathrm{L}^{-1}$, and after that the biohydrogen production decreased with further increase in glucose concentration. A maximum biohydrogen yield of $2.34 \mathrm{~mol} \mathrm{H}_{2} \mathrm{~mol}^{-1}$ glucose was obtained when initial glucose concentration was $10,000 \mathrm{mg} \mathrm{L}^{-1}$. Furthermore, when initial glucose concentration was increased to $13,000 \mathrm{mg} \mathrm{L}^{-1}$ and $16,000 \mathrm{mg} \mathrm{L}^{-1}$, the hydrogen yield obtained was 2.02 and $1.46 \mathrm{~mol} \mathrm{H}_{2} \mathrm{~mol}^{-1}$ glucose, respectively (Figure 1). The decrease in biohydrogen production at higher substrate concentrations might be due to the formation of more volatile fatty acids (data not shown here) which resulted in over-acidification of bacterial cultures, thereby reducing the medium $\mathrm{pH}$, and thus inhibited fermentation. Several reports have shown that although high substrate concentrations showed high biohydrogen production initially, they tend to drop to low levels due to simultaneous acid inhibition, and increased partial pressure of hydrogen in the flask [30, 31]. Maintaining the carbon source levels at an optimum, in bioreactors, is an important parameter during pilot-scale trials and during the continuous production of biohydrogen. Failure to do so could affect the growth rate of the microorganism, its specific substrate utilization rate, enzyme activity, and overall yield of the process itself. Hence, to avoid the formation of volatile fatty acids and the phenomena of substrate inhibitions, the concentration of the substrate (glucose) in the liquid-phase must be maintained at optimal levels.

3.2. Effect of Medium $p H$. The profile of cumulative biohydrogen gas production at various initial medium $\mathrm{pH}$ conditions is shown in Figure 2. The optimum initial glucose concentration of $10,000 \mathrm{mg} \mathrm{L}^{-1}$ was constantly maintained 


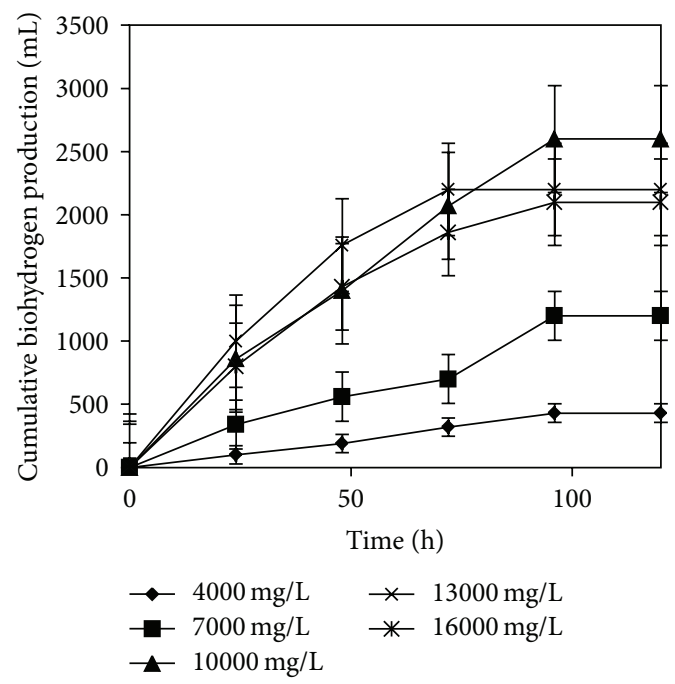

(a)

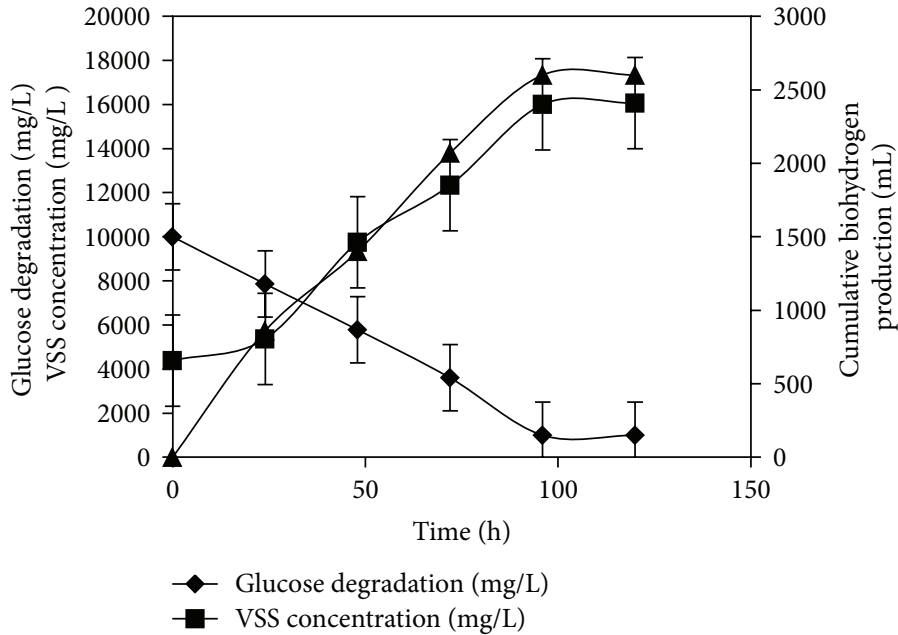

(b)

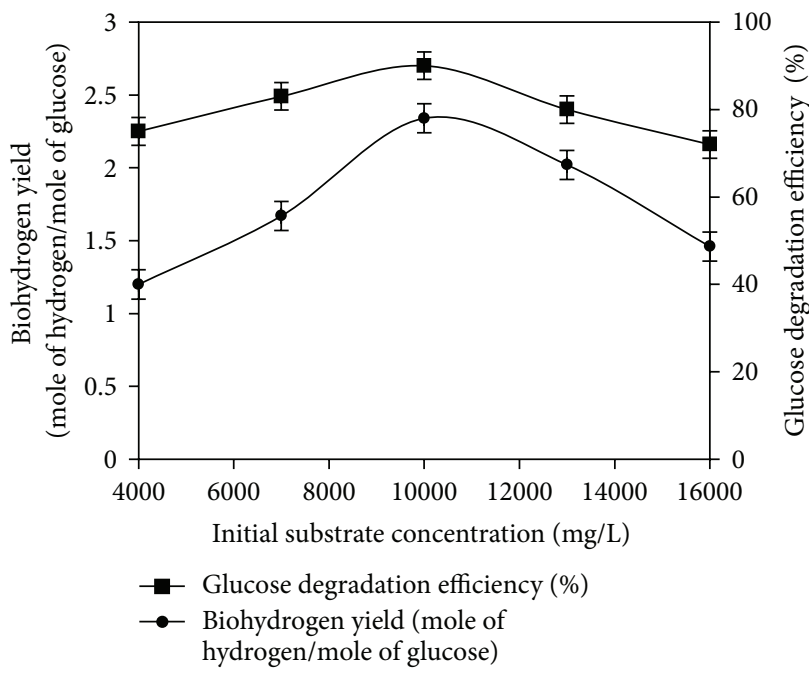

(c)

FIGURE 1: (a) Profile of cumulative biohydrogen production at various initial glucose concentrations. (b) Dynamic profile of glucose degradation, biomass concentration, and cumulative biohydrogen production. (c) Biohydrogen yield and glucose degradation efficiency for various initial glucose concentrations.

for these experiments. The substrate degradation efficiencies obtained were $83,75,80,90$, and $83 \%$, respectively, at initial $\mathrm{pH}$ values of $4.5,5.0,5.5,6.0$, and 6.5 . The final $\mathrm{pH}$ of these test vials at the end of the test period ranged from 1.9 to 3.4. The medium $\mathrm{pH}$ is an important operational parameter for hydrogen production, since it affects anaerobic pathways and the activities of hydrogenase enzymes [32]. When the initial medium $\mathrm{pH}$ was varied by keeping initial substrate concentration constant at $10,000 \mathrm{mg} \mathrm{L}^{-1}$, the maximum hydrogen yield of $2.3 \mathrm{~mol} \mathrm{H}_{2} \mathrm{~mol}^{-1}$ glucose was obtained at an initial $\mathrm{pH}$ of 6.0 (Figure 2). Initially, when the medium $\mathrm{pH}$ was at 4.5 , the lowest hydrogen yield of $0.9 \mathrm{~mol} \mathrm{H}_{2} \mathrm{~mol}^{-1}$ glucose obtained indicated that the higher acidic condition inhibited the fermentation. The hydrogen yield substantially increased to $2.3 \mathrm{~mol} \mathrm{H}_{2} \mathrm{~mol}^{-1}$ glucose at the $\mathrm{pH}$ of 6.0. The hydrogen yield decreased to $2.0 \mathrm{~mol} \mathrm{H}_{2} \mathrm{~mol}^{-1}$ glucose at a higher
$\mathrm{pH}$ value (6.5). It was found that, under near neutral $\mathrm{pH}$ condition, a significant amount of substrates was consumed by bacterial growth other than hydrogen production which was verified by the higher biomass concentration at higher $\mathrm{pH}$. Thus, it could be stated that the favourable $\mathrm{pH}$ for this mixed bacterial culture was 6.0. Similar results of maximum hydrogen production at the $\mathrm{pH}$ of 6.0 were reported [33].

3.3. Effect of $\mathrm{Fe}^{2+}$ Concentration. Figure 3 illustrates the effect of fermentation time on the cumulative hydrogen production in batch tests under different $\mathrm{Fe}^{2+}$ concentrations. The values of cumulative biohydrogen production for five different $\mathrm{Fe}^{2+}$ concentrations: $100,200,300,400$, and $500 \mathrm{mg} \mathrm{L}^{-1}$ were 3040 , $2800,2610,2300$, and $1180 \mathrm{~mL}$, respectively, and the corresponding substrate degradation efficiencies were 94, 92, 91, 90 , and $80 \%$. Hydrogen yields of $2.6,2.3,2.1,1.8$, and $0.9 \mathrm{~mol}$ 


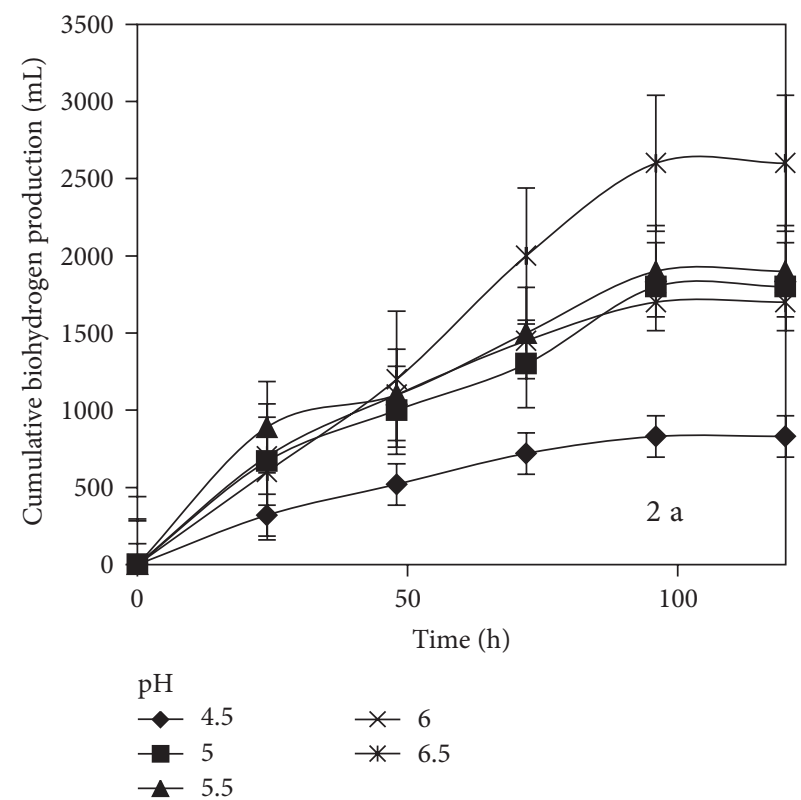

(a)

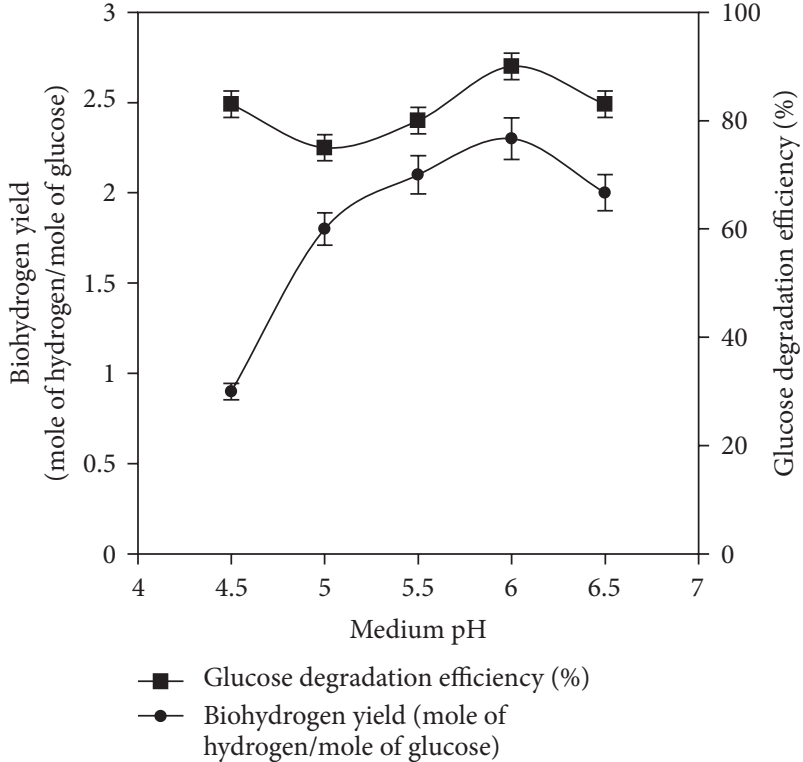

(b)

FIGURE 2: (a) Profile of cumulative biohydrogen production at various medium pH. (b) Biohydrogen yield and glucose degradation efficiency for various medium $\mathrm{pH}$.

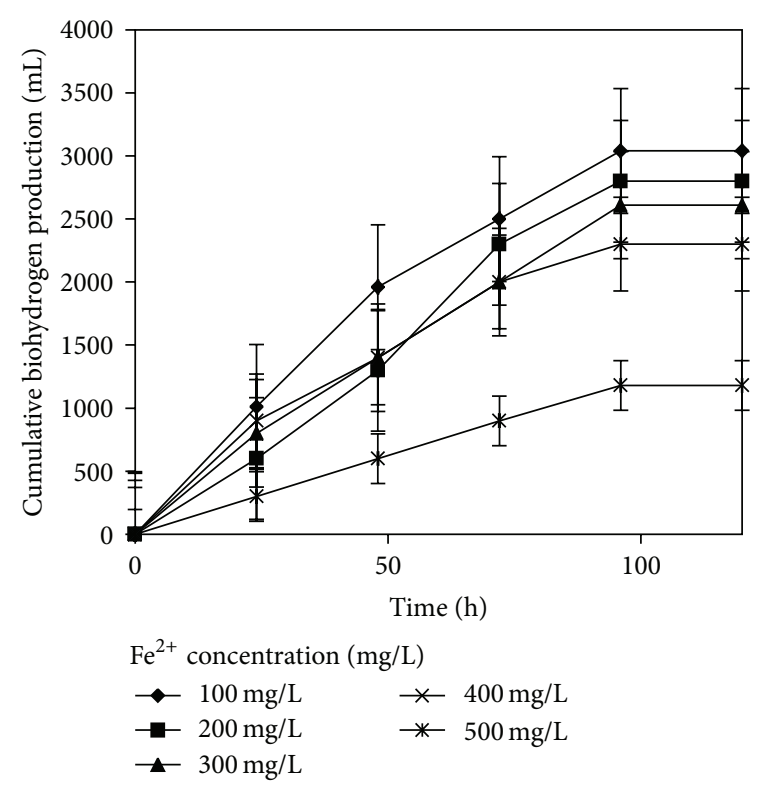

(a)

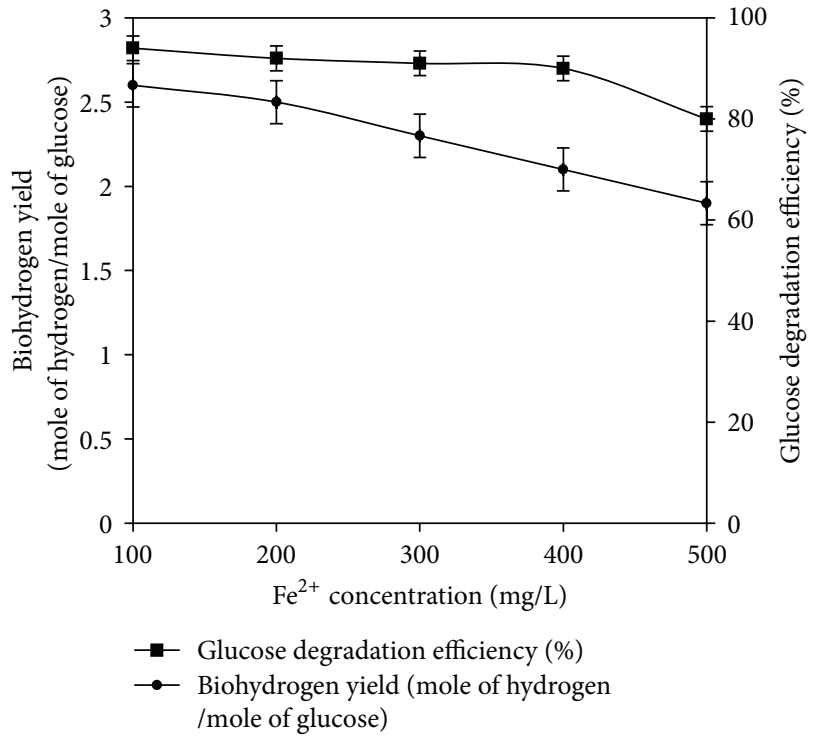

(b)

FIGURE 3: (a) Profile of cumulative biohydrogen production at different $\mathrm{Fe}^{2+}$ concentrations. (b) Biohydrogen yield and glucose degradation efficiency for various $\mathrm{Fe}^{2+}$ concentrations.

$\mathrm{H}_{2} \mathrm{~mol}^{-1}$ glucose were obtained for various concentrations of iron as illustrated in Figure 3. At $100 \mathrm{mg} \mathrm{L}^{-1}$ of $\mathrm{Fe}^{2+}$ concentration, the biohydrogen production was at its maximum (2.6 $\mathrm{mol} \mathrm{H}_{2} \mathrm{~mol}^{-1}$ glucose), and it was found to decrease when the $\mathrm{Fe}^{2+}$ concentration was increased (Figure 3). Similar trend was obtained by previous researchers [34-36]. The addition/presence of $\mathrm{Fe}^{2+}$ concentration in the fermentation medium could influence the fermentative hydrogen production by influencing the activity of hydrogenase enzyme. The literature reports have shown that metal ions affect the microrganisms involved in hydrogen fermentation, beyond a threshold concentration range, and these effects include the 
TABLE 1: Comparison of kinetic parameters for Monod model.

\begin{tabular}{|c|c|c|c|c|c|c|}
\hline Process & Type of culture & Substrate & $\mu_{\max }$ & $K_{s}$ & $R^{2}$ & Author \\
\hline Batch & Mixed anaerobic culture & Sucrose & $0.078 \mathrm{~h}^{-1}$ & - & - & {$[26]$} \\
\hline Batch & $\begin{array}{c}\text { Clostridium pasteurianum } \\
\mathrm{CH} 4\end{array}$ & Sucrose & $0.31 \mathrm{~h}^{-1}$ & $4.39 \mathrm{~g} \mathrm{COD} \mathrm{L}^{-1}$ & 0.935 & {$[37]$} \\
\hline Batch & Mixed sludge & Glucose & $0.03 \mathrm{~g}$ biomass/g biomass/day & - & - & {$[38]$} \\
\hline Batch & Mixed culture & Xylose & $0.17 \mathrm{~h}^{-1}$ & $0.75 \mathrm{~g} / \mathrm{L}$ & - & {$[39]$} \\
\hline Sequential batch & Activated sludge & Glucose & $0.125 \mathrm{~h}^{-1}$ & - & - & {$[40]$} \\
\hline Batch & Acidogenic mixed culture & Glucose & $0.163 \mathrm{~h}^{-1}$ & - & - & {$[41]$} \\
\hline Batch & Acidogenic mixed culture & Fructose & $0.108 \mathrm{~h}^{-1}$ & - & - & {$[41]$} \\
\hline Batch & $\begin{array}{l}\text { Anaerobic acclimatized } \\
\text { banana stem sludge }\end{array}$ & Banana stem waste & $0.111 \mathrm{~h}^{-1}$ & $0.330 \mathrm{~g} / \mathrm{L}$ & 0.902 & {$[42]$} \\
\hline Batch & $\begin{array}{l}\text { Sediments of Pichavaram } \\
\text { mangroves }\end{array}$ & Glucose & $0.166 \mathrm{~h}^{-1}$ & $0.112 \mathrm{~g} / \mathrm{L}$ & 0.971 & Present study \\
\hline
\end{tabular}

TABLE 2: Comparison of kinetic parameters of logistic model.

\begin{tabular}{lccccc}
\hline Process & Type of culture & Substrate & $k\left(\mathrm{~h}^{-1}\right)$ & $R^{2}$ & Author \\
\hline Batch & Rhodobacter sphaeroides & Malic acid & 0.098 & 0.98 & {$[25]$} \\
Batch & Sludge & Glucose & - & 0.99 & {$[26]$} \\
Batch & Sediments of Pichavaram mangroves & Glucose & 0.034 & 0.943 & Present study \\
\hline
\end{tabular}

following: decreased hydrogen production rate, an increase in lag-phase time, and formation of soluble microbial products [34].

\subsection{Kinetics of Biohydrogen Production in Batch Culture}

3.4.1. Cell Growth Kinetics as a Function of Substrate. Monod kinetics was applied to study the cell growth kinetics during biohydrogen production. Monod kinetics is given by the following equation:

$$
\mu=\frac{1}{x} \frac{d x}{d t}=\frac{\mu_{\max } S}{K_{s}+S},
$$

where $\mu$ is the specific growth rate $\left(\mathrm{h}^{-1}\right), \mu_{\max }$ is the maximum specific growth rate $\left(\mathrm{h}^{-1}\right), x$ is the cell concentration $\left(\mathrm{g} \mathrm{L}^{-1}\right)$, and $K_{s}$ is the substrate consumption rate constant $\left(\mathrm{g} \mathrm{L}^{-1}\right)$. Equation (1) may be linearized, as shown in (2) to estimate the kinetic parameters, and regression analysis is used to find the best fit for a straight line on a plot of $1 / \mu$ versus $1 / S$ to determine the values of $\mu_{\max }$ and $K_{s}$ (Figure 4):

$$
\frac{1}{\mu}=\frac{K_{s}}{\mu_{\max }} \cdot \frac{1}{S}+\frac{1}{\mu_{\max }} .
$$

Table 1 shows the different values of kinetic parameters obtained from Monod model, while Figure 4 shows the correlation between the model fitted and experimental values. The $\mu_{\max }$ and $K_{s}$ were calculated as $0.166 \mathrm{~h}^{-1}$ and $0.112 \mathrm{~g} \mathrm{~L}^{-1}$ respectively.

3.4.2. Cell Growth Rate as a Function of Cell Concentration. The specific growth rate for the logistic curve relates the change of specific growth rate with respect to change in cell concentration $(x)$. The Riccatti equation is given by the following equation:

$$
\frac{d x}{d t}=k x(1-\beta x)
$$

where $\beta=1 / x_{\max }$.

On integrating and applying the limits,

$$
\begin{gathered}
\int_{x_{0}}^{x} \frac{d x}{x(1-\beta x)}=k \int_{0}^{t} d t \\
e^{k t}=\frac{x\left(1-\beta x_{0}\right)}{x_{0}(1-\beta x)} .
\end{gathered}
$$

Rearranging the above equation, cell concentration $x$ is given by

$$
x=\frac{x_{0} e^{k t}}{1-\beta x_{0}\left(1-e^{k t}\right)} .
$$

$x_{\max }$ and $k$ kinetic parameters are calculated using logistic curve.

However, for the purposes of batch hydrogen production experiments, where the initial substrate concentrations and the inoculation volume are kept constant, the logistic model is only a fair approximation of the growth curve. From Figure 5, kinetic parameters were estimated and their values were as follows: $k=0.061 \mathrm{~h}^{-1} ; x_{\max }=30.74 \mathrm{gVSS} \mathrm{L}^{-1}$. Table 2 shows the comparison of different kinetic parameters for the logistic model. The experimental and model fitted specific growth rates were significant with high regression coefficient values. From Figure 5, it could be inferred that the model performed well during the simulation of batch reactors performance, with respect to the glucose and biomass concentration. 


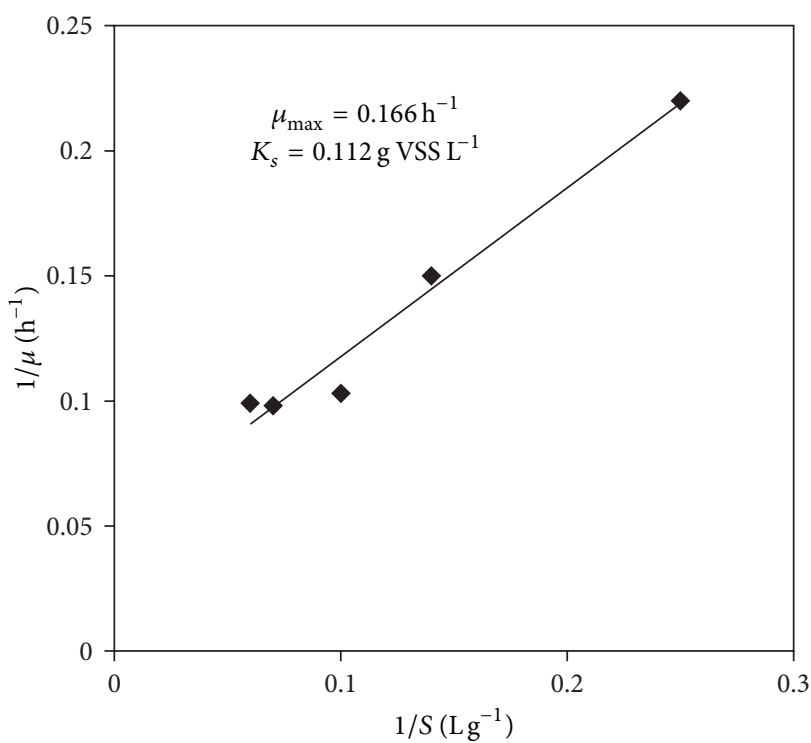

(a)

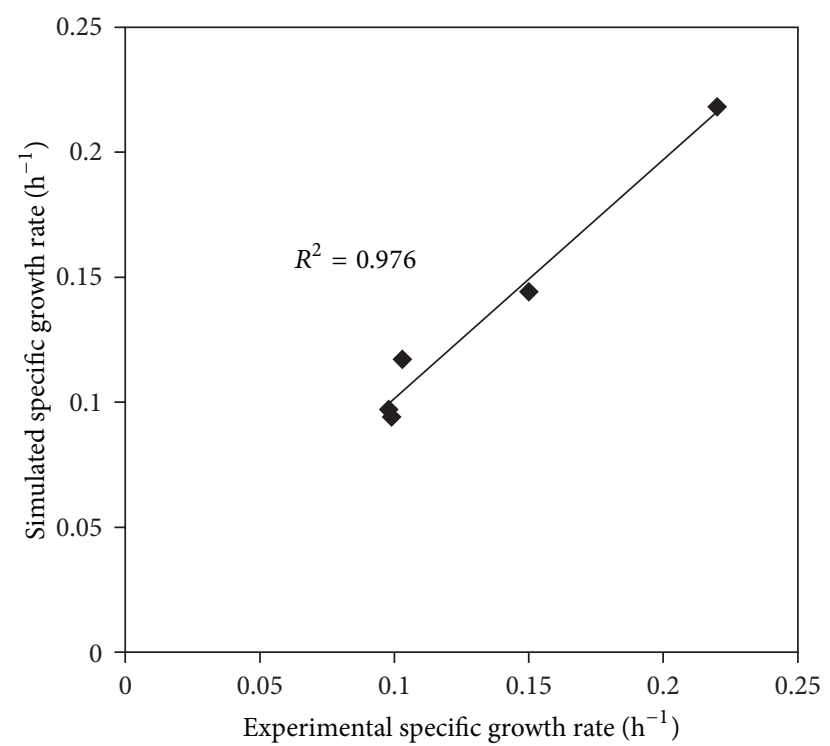

(b)

FIGURE 4: Monod model for substrate utilization kinetics.

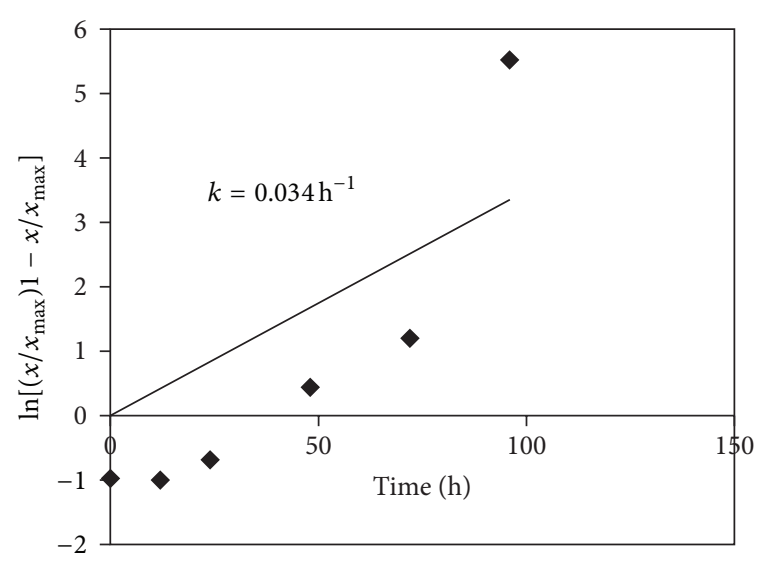

(a)

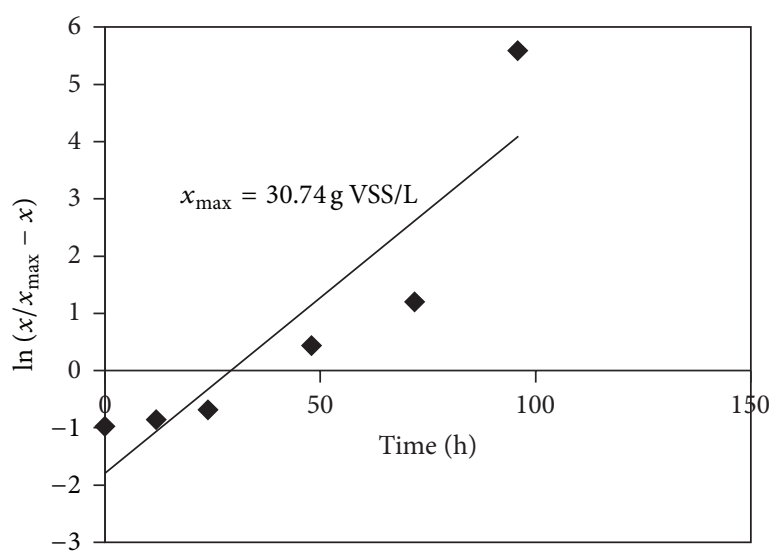

(b)

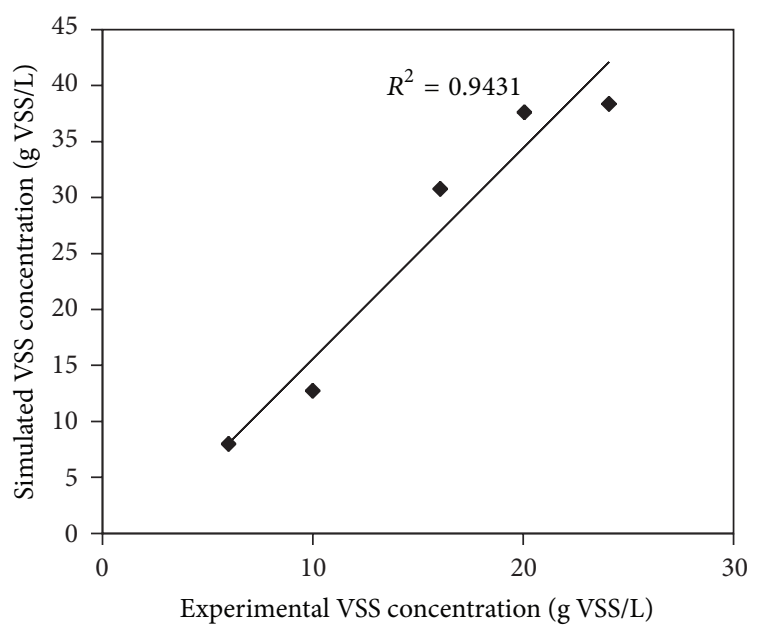

(c)

Figure 5: Logistic model for cell growth kinetics. 
TABLE 3: Comparison of kinetic parameters of Luedeking-Piret model.

\begin{tabular}{lccccc}
\hline Process & Type of culture & Substrate & $Y_{P / x}$ & $R^{2}$ & Author \\
\hline Batch & Clostridium butrycum CGS5 & Xylose & 0.041 & 0.910 & {$[37]$} \\
Batch & Mixed microflora & Wheat stalk & - & $>0.855$ & {$[43]$} \\
Batch & Sediments of Pichavaram mangroves & Glucose & 11.04 & 0.999 & Present study \\
\hline
\end{tabular}

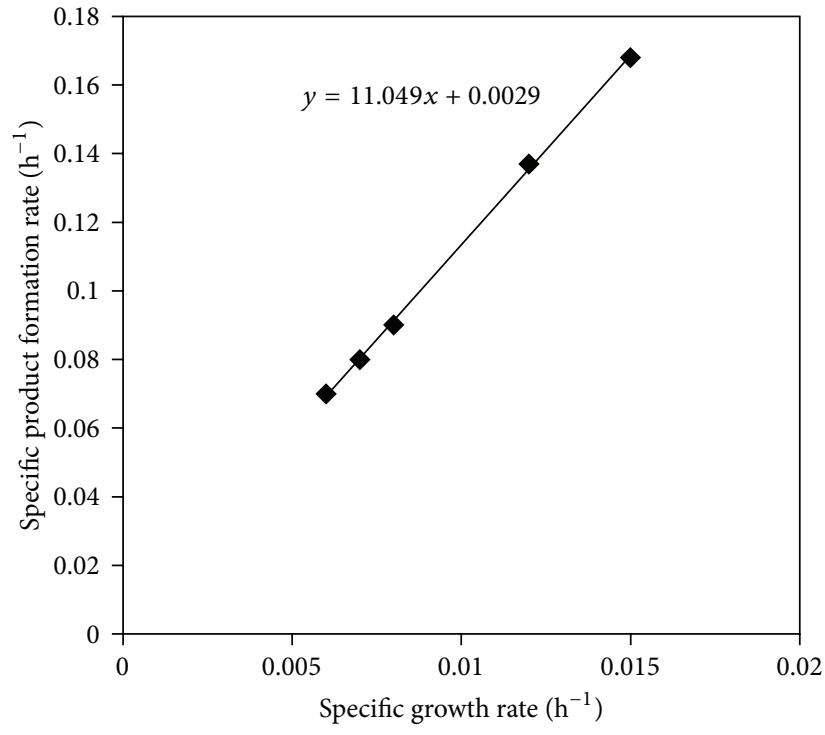

(a)

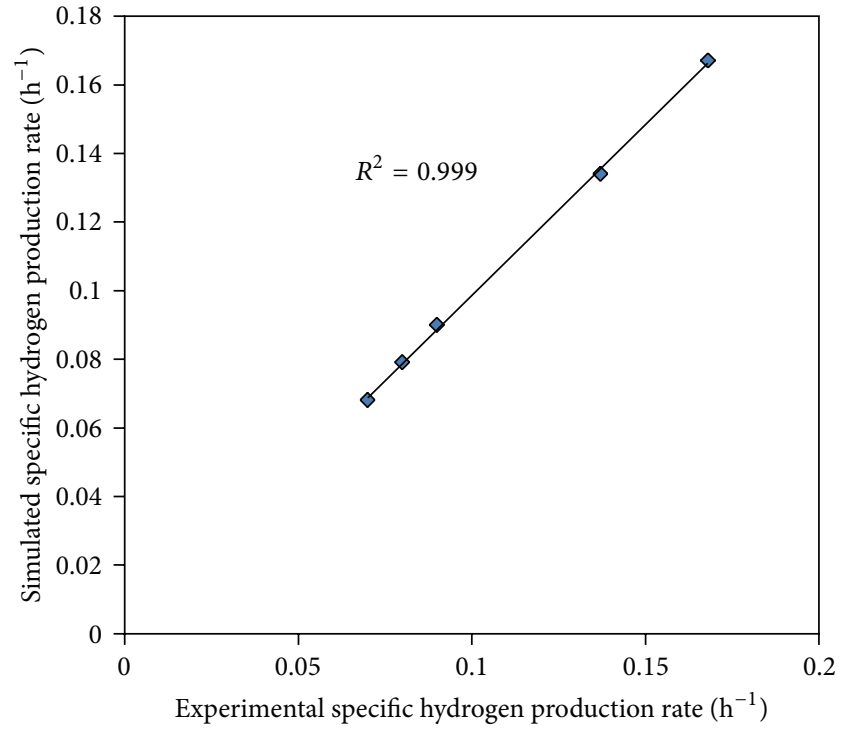

(b)

FIgURE 6: Luedeking-Piret model for product formation kinetics.

3.4.3. Cell Growth Rate as a Function of Product Formation. The Luedeking-Piret model shown in (6) has been widely used to describe the relationship between hydrogen producing bacterial growth rate and product formation rate:

$$
\frac{d p}{d t}=Y_{P / x} \frac{d x}{d t}+\beta x
$$

where $d p / d t$ is the product formation rate $\left(\mathrm{h}^{-1}\right), d x / d t$ is the specific growth rate $\left(\mathrm{h}^{-1}\right), P$ is the product (biohydrogen production), $x$ is the cell concentration $\left(\mathrm{gL}^{-1}\right), Y_{P / x}$ is the growth associate product yield coefficient, and $\beta$ is the nongrowth associated product yield coefficient.

Table 3 shows the values of different kinetic parameters estimated for this model. A plot of specific growth rate versus product formation rate, as shown in Figure 6, indicates that hydrogen is purely a growth associated product. The growth associate product yield coefficient $\left(Y_{P / x}\right)$ was calculated by plotting specific hydrogen production rate versus specific growth rate, and the value was found to be 11.04. From Figure 6, it could be inferred that the model performed well with $R^{2}$ value of 0.999 .

3.4.4. Microscopic Examination of Hydrogen Producing Granule. Scanning electron micrographs showed that the granules had multiple cracks with cavities on the surface (Figure 7). These cavities were likely to facilitate the passage of nutrients and substrate as well as the release of hydrogen. Bacterial cells were distributed all over the granules.

Furthermore, considering the practicality of this research work, microbiological analyses are warranted at this stage to characterize the dominant anaerobic consortium responsible for biohydrogen production. In general, kinetic models are applied in order to study and assess the metabolic features of defined cultures. Further studies in this field should be aimed at the following aspects: optimization studies with different innocula, substrates and process parameters, evaluation of the performance, and economics of a continuous biohydrogen production processes (bioreactors).

\section{Conclusions}

The results from batch tests showed that initial substrate (glucose) concentration, medium $\mathrm{pH}$, and $\mathrm{Fe}^{2+}$ concentration had influence on the biohydrogen yield. Maximum biohydrogen yields were found to be 2.34, 2.3, and $2.5 \mathrm{~mol} \mathrm{H}_{2} \mathrm{~mol}^{-1}$ glucose at the following conditions: initial substrate concentration $-10,000 \mathrm{mg} \mathrm{L}^{-1}$, medium $\mathrm{pH}-6.0$, and $\mathrm{Fe}^{2+}$ concentration $-100 \mathrm{mg} \mathrm{L}^{-1}$, respectively. The addition of trace metal to the medium at a concentration of $100 \mathrm{mg} \mathrm{L}^{-1}$ was found to enhance biohydrogen production although higher metal ion concentrations reduced biohydrogen production. The kinetics of batch anaerobic hydrogen production was estimated by fitting the experimental data 


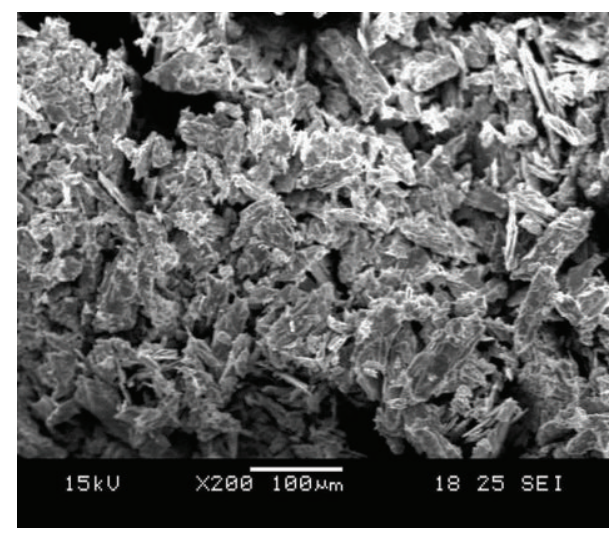

(a)

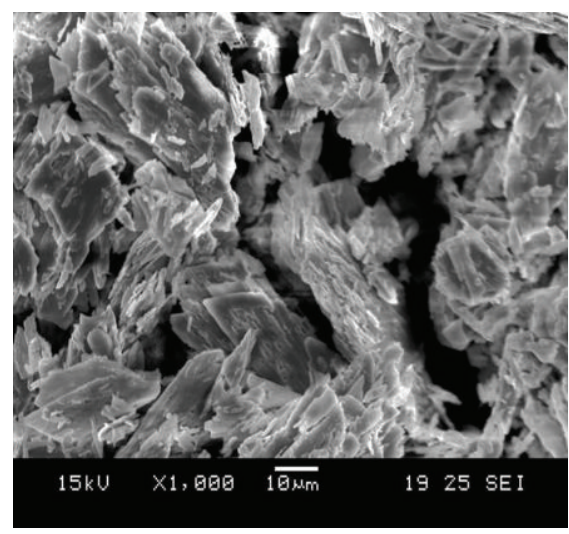

(b)

FIGURE 7: SEM image of typical hydrogen-producing granule.

to the well-known unstructured kinetic models. The Monod model, logistic model, and Luedeking-Piret model were used to describe the kinetics of cell growth rate as a function of substrate, cell concentration, and product formation, respectively, in the hydrogen production process, and the corresponding kinetic constants were estimated. The results showed that high regression co-efficient values $\left(R^{2}\right)$ were obtained between the model fitted and the experimental observations for the different models, namely, as 0.976, 0.943, and 0.999 , respectively.

\section{Nomenclature}

$$
\begin{array}{ll}
\mu: & \text { Specific growth rate }\left(\mathrm{h}^{-1}\right) \\
\mu_{\max }: & \text { Maximum specific growth rate }\left(\mathrm{h}^{-1}\right) \\
x: & \text { Microbial concentration }\left(\mathrm{g} \mathrm{VSS} \mathrm{L}^{-1}\right) \\
x_{0}: & \text { Initial microbial concentrations }\left(\mathrm{g} \mathrm{VSS} \mathrm{L}^{-1}\right) \\
K_{s}: & \text { Substrate consumption rate }\left(\mathrm{g} \mathrm{L}^{-1}\right) \\
k: & \text { Apparent specific growth rate }\left(\mathrm{h}^{-1}\right) \\
x_{\max }: & \text { Maximum microbial concentration } \\
P: & \text { (g VSS } \left.\mathrm{L}^{-1}\right) \\
Y_{P / x}: & \text { Growth associate product yield coefficient } \\
\beta: & \text { Non-growth associated product yield } \\
& \text { coefficient. }
\end{array}
$$

\section{Conflict of Interests}

The authors declare that there is no conflict of interests.

\section{Authors' Contribution}

The authors of this research article contributed to a similar extent overall and agreed to submit the paper.

\section{Acknowledgments}

The authors thank the Ministry of Earth Sciences, Government of India, New Delhi, for funding this research project (No: MOES/MRDF-11/1/25/P/09-PC-III) and Pollution Control Research Laboratory, Department of Chemical Engineering, Annamalai University, India, for laboratory and analytical facilities.

\section{References}

[1] International energy outlook, "U.S. Energy Information Administration," pp. 300, 2013.

[2] D. B. Levin, L. Pitt, and M. Love, "Biohydrogen production: prospects and limitations to practical application," International Journal of Hydrogen Energy, vol. 29, no. 2, pp. 173-185, 2004.

[3] S. Venkata Mohan, Y. Vijaya Bhaskar, and P. N. Sarma, "Biohydrogen production from chemical wastewater treatment in biofilm configured reactor operated in periodic discontinuous batch mode by selectively enriched anaerobic mixed consortia," Water Research, vol. 41, no. 12, pp. 2652-2664, 2007.

[4] M. T. Skonieczny, Biological hydrogen production from industrial wastewater with Clostridium beijerinckii [M.S. dissertation], McGill University, 2008.

[5] G. E. Diwani, N. K. Attia, and S. I. Hawash, "Development and evaluation of biodiesel fuel and by-products from jatropha oil," International Journal of Environmental Science and Technology, vol. 6, no. 2, pp. 219-224, 2009.

[6] H. Le Man, S. K. Behera, and H. S. Park, "Optimization of operational parameters for ethanol production from korean food waste leachate," International Journal of Environmental Science and Technology, vol. 7, no. 1, pp. 157-164, 2010.

[7] H. N. Abubackar, M. C. Veiga, and C. Kennes, "Biological conversion of carbon monoxide: rich syngas or waste gases to bioethanol," Biofuels, Bioproducts and Biorefining, vol. 5, no. 1, pp. 93-114, 2011.

[8] P. Mullai, M. K. Yogeswari, and K. Sridevi, "Optimisation and enhancement of biohydrogen production using nickel nanoparticles-a novel approach," Bioresource Technology, vol. 141, pp. 212-219, 2013.

[9] P. Mullai, K. Sampath, and P. L. Sabarathinam, "Kinetic models anaerobic digestion of penicillin-G wastewater," Chemical Engineering World, vol. 38, no. 12, pp. 161-164, 2003.

[10] P. Mullai, S. Arulselvi, H.-H. Ngo, and P. L. Sabarathinam, "Experiments and ANFIS modelling for the biodegradation 
of penicillin-G wastewater using anaerobic hybrid reactor," Bioresource Technology, vol. 102, no. 9, pp. 5492-5497, 2011.

[11] P. Mullai, H. H. Ngo, and P. L. Sabarathinam, "Substrate removal kinetics of an anaerobic hybrid reactor treating pharmaceutical wastewater," Journal of Water Sustainability, vol. 1, no. 3, pp. 301312, 2011.

[12] R. Kothari, D. P. Singh, V. V. Tyagi, and S. K. Tyagi, "Fermentative hydrogen production-an alternative clean energy source," Renewable and Sustainable Energy Reviews, vol. 16, no. 4, pp. 2337-2346, 2012.

[13] F. R. Hawkes, R. Dinsdale, D. L. Hawkes, and I. Hussy, "Sustainable fermentative hydrogen production: challenges for process optimisation," International Journal of Hydrogen Energy, vol. 27, no. 11-12, pp. 1339-1347, 2002.

[14] N. Ren, J. Li, B. Li, Y. Wang, and S. Liu, "Biohydrogen production from molasses by anaerobic fermentation with a pilot-scale bioreactor system," International Journal of Hydrogen Energy, vol. 31, no. 15, pp. 2147-2157, 2006.

[15] S. Robaire, Biological hydrogen production using Citrobacter amalonaticus Y19 to catalyze the water-gas shift reaction [M.S. dissertation], McGill University, 2006.

[16] K. Vijayaraghavan and M. A. M. Soom, "Trends in biohydrogen generation-a review," Environmental Sciences, vol. 3, pp. 255-271, 2006.

[17] K. Kathiresan, "A review of studies on Pichavaram mangrove, Southeast India," Hydrobiologia, vol. 430, no. 1-3, pp. 185-205, 2000.

[18] K. Kathiresan, "Why are mangroves degrading?" Current Science, vol. 83, no. 10, pp. 10-25, 2002.

[19] D. Zhu, G. Wang, H. Qiao, and J. Cai, "Fermentative hydrogen production by the new marine Pantoea agglomerans isolated from the mangrove sludge," International Journal of Hydrogen Energy, vol. 33, no. 21, pp. 6116-6123, 2008.

[20] J. Wang and W. Wan, "Kinetic models for fermentative hydrogen production: a review," International Journal of Hydrogen Energy, vol. 34, no. 8, pp. 3313-3323, 2009.

[21] R. Zhao, H. Liu, H. Hu et al., "A fundamental research on combustion chemical kinetic model's precision property," Science China Technological Sciences, vol. 53, no. 8, pp. 2222-2227, 2010.

[22] P. Mullai, E. R. Rene, H. S. Park, and P. L. Sabarathinam, "Adaptive network based fuzzy interference system (ANFIS) modeling of an anaerobic wastewater treatment process," in Handbook of Research on Industrial Informatics and Manufacturing Intelligence: Innovations and Solutions, M. A. Khan and A. Q. Ansari, Eds., pp. 252-270, IGI, New York, NY, USA, 2012.

[23] J. E. Bailey and D. F. Ollis, Biochemical Engineering Fundamentals, Tata MaGraw-Hill, New Delhi, India, 1986.

[24] K. Nath and D. Das, "Modeling and optimization of fermentative hydrogen production," Bioresource Technology, vol. 102, no. 18, pp. 8569-8581, 2011.

[25] H. Koku, I. Eroǧlu, U. Gündüz, M. Yücel, and L. Türker, "Kinetics of biological hydrogen production by the photosynthetic bacterium Rhodobacter sphaeroides O.U. 001," International Journal of Hydrogen Energy, vol. 28, no. 4, pp. 381-388, 2003.

[26] Y. Mu, G. Wang, and H.-Q. Yu, "Kinetic modeling of batch hydrogen production process by mixed anaerobic cultures," Bioresource Technology, vol. 97, no. 11, pp. 1302-1307, 2006.

[27] J. Niessen, F. Harnisch, M. Rosenbaum, U. Schröder, and F. Scholz, "Heat treated soil as convenient and versatile source of bacterial communities for microbial electricity generation," Electrochemistry Communications, vol. 8, no. 5, pp. 869-873, 2006.
[28] APHA, Standard Methods for the Examination of Waste and Wastewater, American Public Health Associations, New York, NY, USA, 1995.

[29] G. L. Miller, "Use of dinitrosalicylic acid reagent for determination of reducing sugar," Analytical Chemistry, vol. 31, no. 3, pp. 426-428, 1959.

[30] J. Wang and W. Wan, "The effect of substrate concentration on biohydrogen production by using kinetic models," Science in China B, vol. 51, no. 11, pp. 1110-1117, 2008.

[31] W. M. Alalayah, M. S. Kalil, A. A. H. Kadhum, J. M. Jahim, and N. M. Alauj, "Effect of environmental parameters on hydrogen production using Clostridium saccharoperbutylacetonicum N14(ATCC 13564)," American Journal of Environmental Sciences, vol. 5, no. 1, pp. 80-86, 2009.

[32] S. K. Khanal, W.-H. Chen, L. Li, and S. Sung, "Biological hydrogen production: effects of $\mathrm{pH}$ and intermediate products," International Journal of Hydrogen Energy, vol. 29, no. 11, pp. 1123-1131, 2004.

[33] M. Ferchichi, E. Crabbe, G.-H. Gil, W. Hintz, and A. Almadidy, "Influence of initial $\mathrm{pH}$ on hydrogen production from cheese whey," Journal of Biotechnology, vol. 120, no. 4, pp. 402-409, 2005.

[34] Y. J. L. Young Joon Lee, T. Miyahara, and T. Noike, "Effect of iron concentration on hydrogen fermentation," Bioresource Technology, vol. 80, no. 3, pp. 227-231, 2001.

[35] H. Yang and J. Shen, "Effect of ferrous iron concentration on anaerobic bio-hydrogen production from soluble starch," International Journal of Hydrogen Energy, vol. 31, no. 15, pp. 2137-2146, 2006.

[36] J. Wang and W. Wan, "Effect of $\mathrm{Fe}^{2+}$ concentration on fermentative hydrogen production by mixed cultures," International Journal of Hydrogen Energy, vol. 33, no. 4, pp. 1215-1220, 2008.

[37] Y.-C. Lo, W.-M. Chen, C.-H. Hung, S.-D. Chen, and J.-S. Chang, "Dark $\mathrm{H}_{2}$ fermentation from sucrose and xylose using $\mathrm{H}_{2}$ producing indigenous bacteria: feasibility and kinetic studies," Water Research, vol. 42, no. 4-5, pp. 827-842, 2008.

[38] Y. Sharma and B. Li, "Optimizing hydrogen production from organic wastewater treatment in batch reactors through experimental and kinetic analysis," International Journal of Hydrogen Energy, vol. 34, no. 15, pp. 6171-6180, 2009.

[39] P. Kongjan, B. Min, and I. Angelidaki, "Biohydrogen production from xylose at extreme thermophilic temperatures $\left(70^{\circ} \mathrm{C}\right)$ by mixed culture fermentation," Water Research, vol. 43, no. 5, pp. 1414-1424, 2009.

[40] F. J. Fernández-Morales, J. Villaseñor, and D. Infantes, "Modeling and monitoring of the acclimatization of conventional activated sludge to a biohydrogen producing culture by biokinetic control," International Journal of Hydrogen Energy, vol. 35, no. 20, pp. 10927-10933, 2010.

[41] F. J. Fernández, J. Villaseñor, and D. Infantes, "Kinetic and stoichiometric modelling of acidogenic fermentation of glucose and fructose," Biomass and Bioenergy, vol. 35, no. 9, pp. 38773883, 2011.

[42] N. Zainol, "Kinetics of biogas production from banana stem waste," in Biogas, S. Kumar, Ed., p. 408, InTech, Europe, 2012.

[43] X. Yuan, X. Shi, P. Zhang, Y. Wei, R. Guo, and L. Wang, "Anaerobic biohydrogen production from wheat stalk by mixed microflora: kinetic model and particle size influence," Bioresource Technology, vol. 102, no. 19, pp. 9007-9012, 2011. 

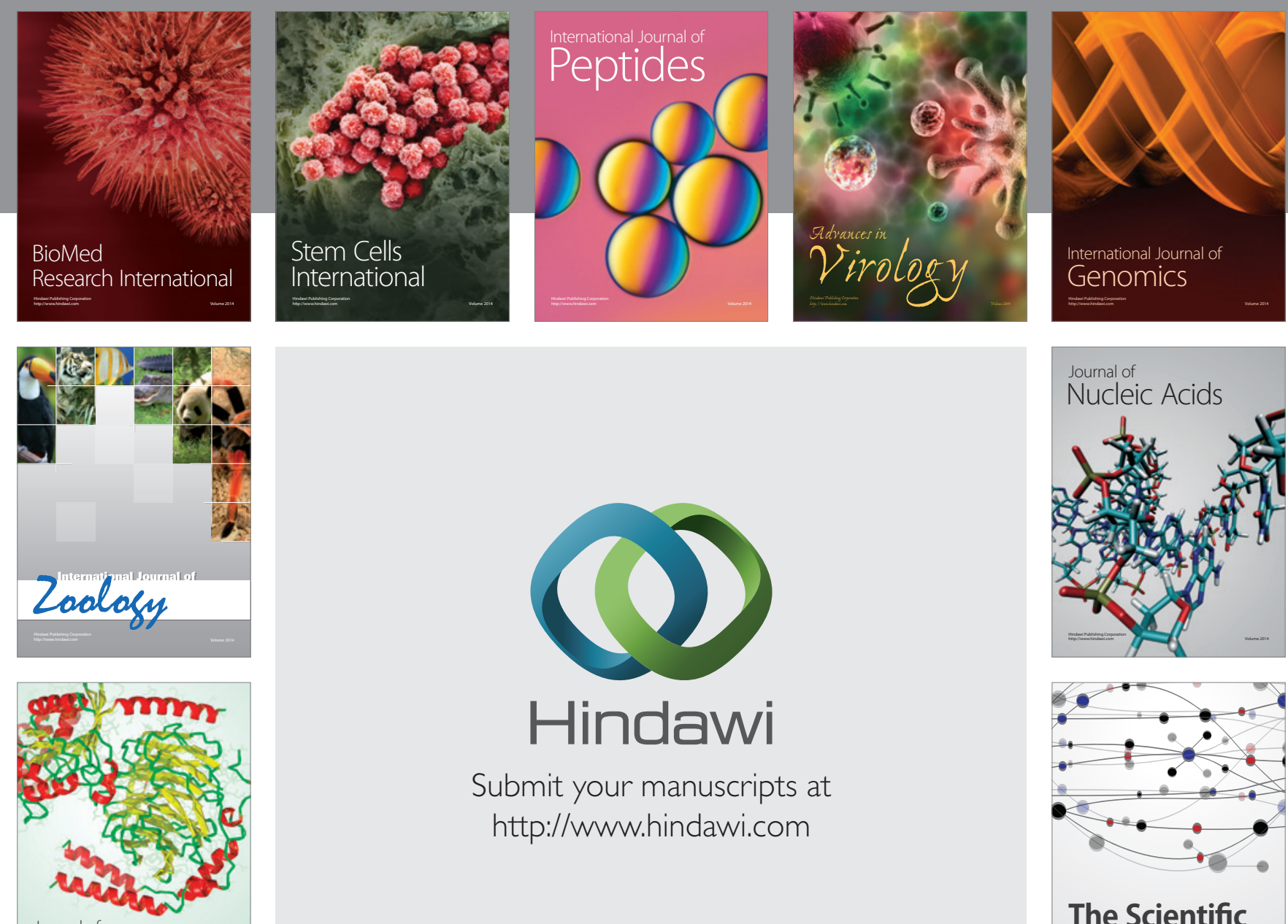

Submit your manuscripts at

http://www.hindawi.com

Journal of
Signal Transduction
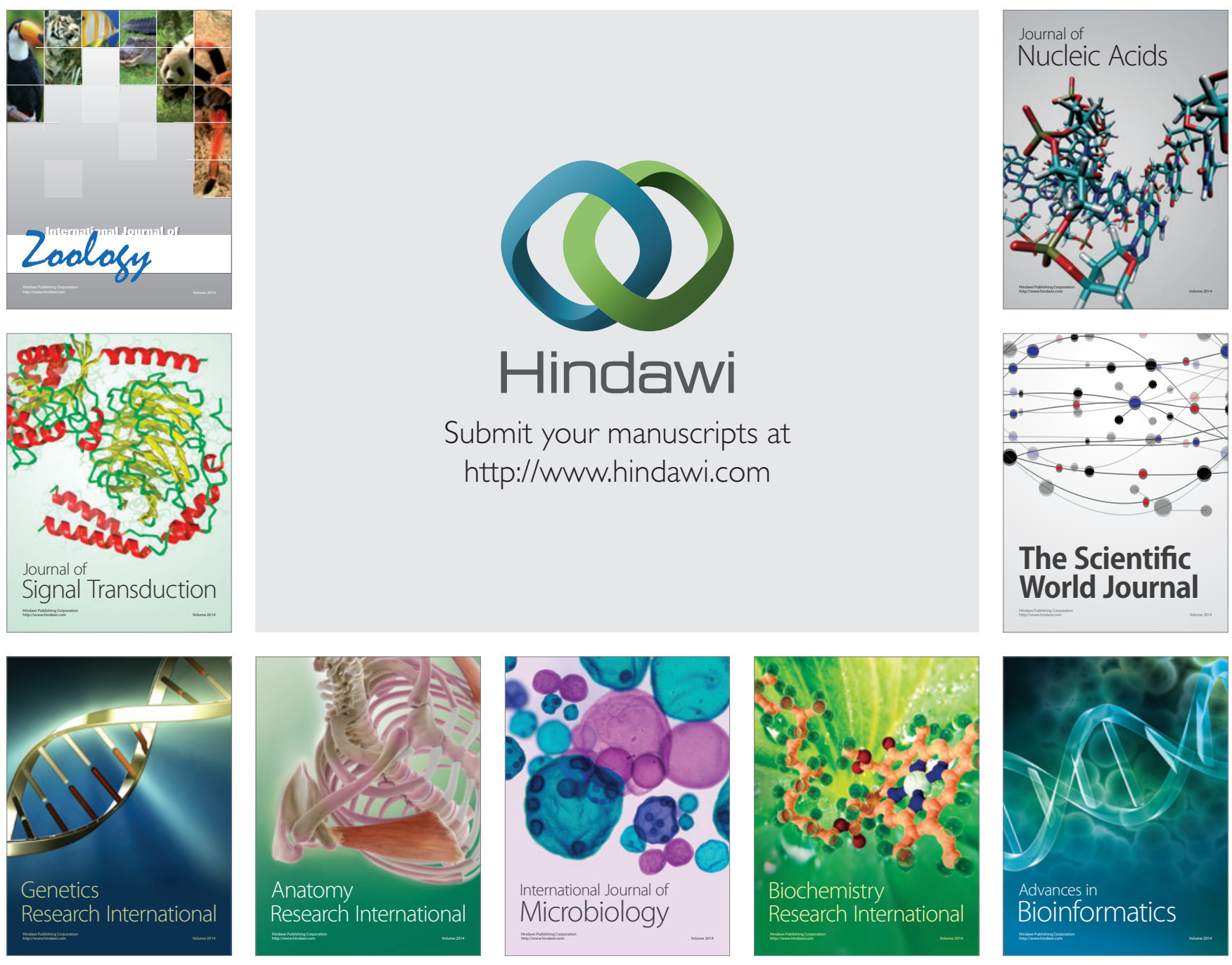

The Scientific World Journal
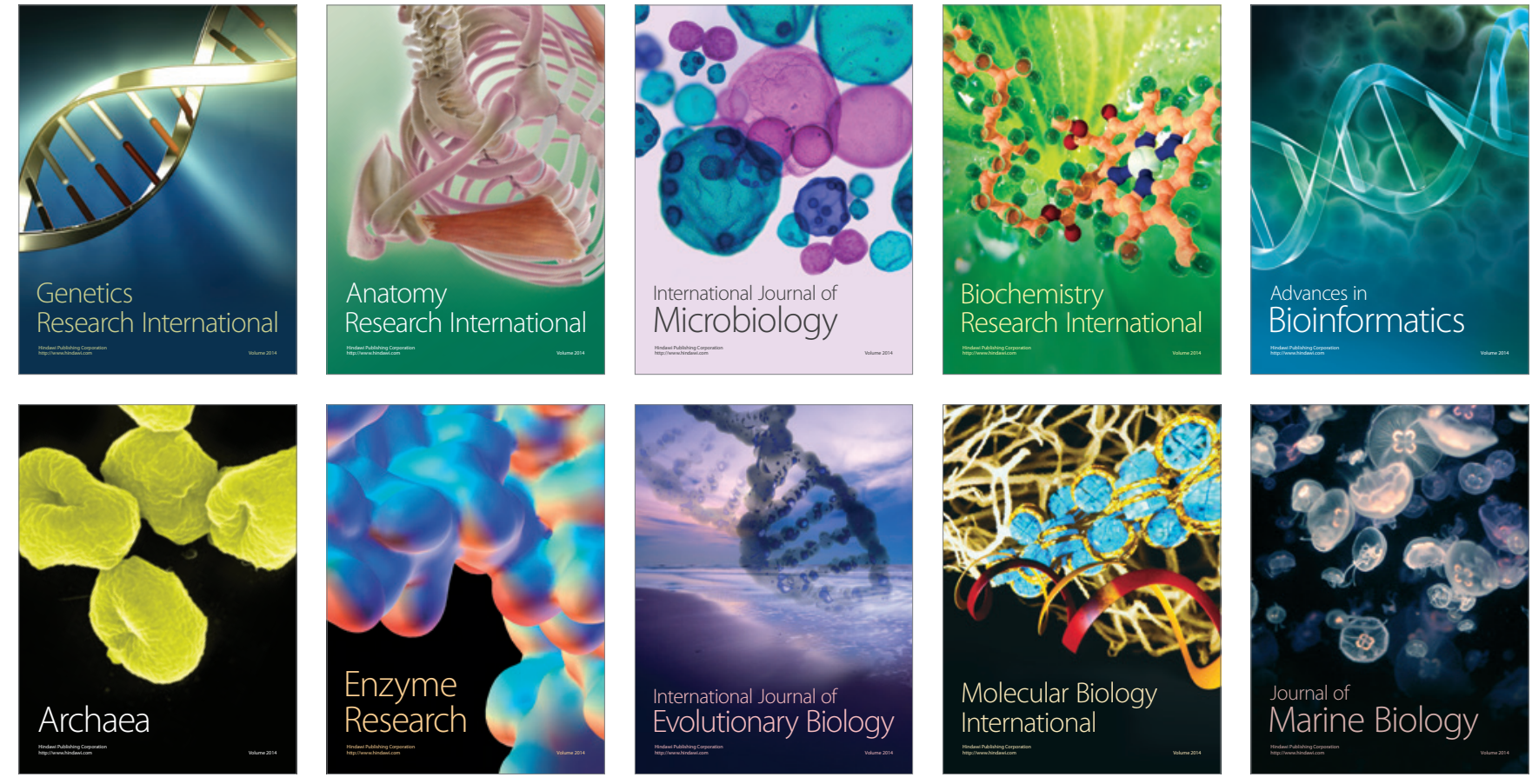